\title{
Dampak Snorkeling Terhadap Persen Tutupan Terumbu Karang Di Pulau Gili Labak Sumenep Madura
}

\author{
Insafitri*, Eka Nurahemma Ning Asih, Wahyu Andy Nugraha \\ Program Studi Ilmu Kelautan, Jurusan Kelautan dan Perikanan, Fakultas Pertanian, \\ Universitas Trunojoyo Madura \\ Jl. Raya Telang, Kamal, Bangkalan, Jawa Timur, 69162, Indonesia \\ Email: insafitri@trunojoyo.ac.id
}

\begin{abstract}
Abstrak
Wisata snorkeling terumbu karang di perairan pulau Gili Labak merupakan salah satu sektor wisata bahari yang sedang dikembangkan oleh pemerintah kebupaten Sumenep Madura sejak tahun 2014 hingga saat ini. Peningkatan jumlah wisatawan yang terjadi pada beberapa tahun terakhir dapat menimbulkan resiko tekanan dan kerusakan ekosistem terumbu karang di area snorkeling secara berkala. Penelitian ini bertujuan untuk mengetahui dampak kegiatan wisatawan sebelum, selama dan sesudah snorkeling terhadap ekosistem terumbu karang yang dikaji dengan mengetahui jenis karang yang mendominasi, status persentase tutupan terumbu karang serta potensi Dampak Wisata Bahari (DWB) snorkeling di lokasi wisata snorkeling pulau Gili Labak Sumenep. Persentase penutupan lifeform karang pulau Gili Labak khususnya di area snorkelling didominasi oleh karang hidup sebanyak $74 \%$ dan unsur abiotik sebesar 22\%. Jenis karang yang mendominasi pulau Gili Labak adalah Acropora Branching sebesar 19,88\% dan Coral Foliose sebesar 10,25\%. Selama waktu 6 minggu pengamatan terjadi penurunan total karang sebesar 0,64\% yang termasuk kategori rusak ringan, dimana sebagian besar kerusakan terjadi pada karang dengan bentuk pertumbahan branching misalnya Acropora Submassive dan Coral Submassive. Penurunan persen tutupan karang yang tinggi terjadi setelah kegiatan snorkeling (after) yang dilakukan oleh wisatawan. Analisa potensi Dampak Wisata Bahari (DWB) snorkeling pada terumbu karang di perairan Gili Labak selama 6 minggu pengamatan masuk dalam kategori rendah yaitu berkisar $0,052 \%$ hingga $0,085 \%$. Faktor penyebab kecilnya nilai presentase Dampak Wisata Bahari (DWB) ini diduga karena waktu pengamatan cenderung pendek dan jenis karang yang mendominasi yaitu Acropora. Acropora memiliki kemampuan regenerasi lebih cepat dibandingkan jenis lainnya.
\end{abstract}

Kata Kunci: Penutupan karang, Snorkeling, Terumbu karang, Gili Labak

Abstract

The Impact of Snorkeling on Percentage of Coral Cover at Gili Labak Island, Sumenep Madura

The snorkeling activity around coral reefs in the waters of Gili Labak is one of the marine tourism sectors that is being developed by the Sumenep Madura district government since 2014. Increasing number of tourists that occurs in recent years pose a risk of pressure and damage to coral reef ecosystems in the snorkeling area. This study aims to determine the impact of tourist activities before, during and after snorkeling on coral reef ecosystems that are studied by knowing the type of dominated coral, the percentage status of coral cover and the potential Impact of snorkeling at the snorkeling sites of the island of Gili Labak Sumenep. The percentage of coral cover in the island of Gili Labak especially in the snorkelling area is dominated by live coral $74 \%$ and abiotic elements by $22 \%$. Coral species that dominate the island of Gili Labak are Acropora Branching at 19.88\% and Coral Foliose at 10.25\%. During the 6-week observation there was a decrease in live coral cover by $0.64 \%$ which was categorized as minor damage, most of the damage occurred to branching Acropora, sub-massive Acropora and Coral Sub-massive. The high percent decrease in coral cover occurred after snorkeling conducted by tourists. Analysis of the potential impact of snorkeling on coral reefs in the waters of Gili Labak for 6 weeks of observation is in the low category, ranging from $0.052 \%$ to $0.085 \%$. The factor causing the small impact of Marine Tourism is presumably 
because the observation time tends to be short and the dominant coral species is Acropora. Acropora has the ability to regenerate faster than other types.

Keywords: Coral cover, Snorkeling, coral reef, Gili Labak

\section{PENDAHULUAN}

Ekosistem terumbu karang mempunyai produktivitas dan keanekaragaman hayati yang tinggi sehingga ekosistem ini mempunyai fungsi dan peranan yang sangat penting dalam lingkungan perairan (Hartoni et al., 2012). Fungsi terumbu karang dari aspek ekologis adalah sebagai habitat bagi banyak biota laut (Hazrul et al., 2016), serta sebagai tempat berkembangbiak ikan, perlindungan pantai dari abrasi, menstabilkan keliling pulau-pulau dan garis pantai dari kikisan ombak yang sangat kuat (Damanhuri, 2003). Ekosistem terumbu karang juga berperan penting dalam sektor ekonomi. Salah satu peran penting terumbu karang dalam sektor ekonomi adalah menciptakan lapangan kerja baru khususnya pengembangan wisata bahari (Akhmad et al., 2018) dan sumber bahan farmasi yaitu sebagai marine natural product dengan kandungan senyawa bioaktifnya (Rozirwan et al., 2014). Potensi terumbu karang sebagai pariwisata dapat dikembangkan menjadi wisata bahari terutama wisata dengan menggunakan daya tarik keindahan ekosistem bawah air (Adibrata, 2013) misalnya kegiatan snorkeling.

Kabupaten Sumenep merupakan salah satu kabupaten di Pulau Madura yang banyak dikelilingi oleh pulau-pulau kecil. Total jumlah pulau di Kabupaten Sumenep sebanyak 126 pulau dengan rincian 48 pulau berpenghuni dan 78 pulau tidak berpenghuni (BPS, 2017). Keberadaan pulau-pulau kecil tersebut memberikan peluang bagi kabupaten Sumenep untuk mengoptimalkan potensi sumber daya alam yang ada untuk mengembangkan sektor pariwisata yaitu wisata pantai dan wisata bahari diantaranya kegiatan snorkeling di ekosistem terumbu karang. Pengembangan sektor wisata bahari khususnya wisata snorkeling di kabupaten Sumenep telah dilakukan di beberapa pulau diantaranya pulau Mamburit, pulau Gili Labak dan pulau Sapeken (BPS, 2018).

Secara demografi Pulau Gili Labak berada diantara pulau Talango dan pulau Gili Genting (BPS, 2009). Perairan pulau Gili Labak mempunyai potensi yang besar dalam pengembangan wisata bahari snorkeling karena hasil dari foto citra LDCM (Landsat Data Continuity Mission) memiliki luas terumbu karang sebesar 66 ha (Muhsoni, 2017). Pengamatan kondisi terumbu karang di Pulau Gili Labek menggunakan metode transek foto bawah air diketahui bahwa penutupan karang hidup di pulau ini seluas $48,7 \%$ dan penutupan terumbu karang dalam kondisi mati sebesar 51,3\% (Muhsoni 2017). Kondisi dan luasan ekosistem terumbu karang tersebut didukung oleh jenis sedimen yang mendominasi pulau Gili Labak yaitu pasir (Putra el al., 2016), serta baku mutu air laut seperti suhu, salinitas, DO, kecerahan dan kedalaman menurut Keputusan Menteri Negara Lingkungan Hidup Nomor 51 tahun 2004 sesuai untuk wisata snorkeling (Muhsoni, 2017)

Perkembangan pulau Gili Labak sebagai lokasi wisata snorkeling dicanangkan sejak tahun 2014 berhasil menarik minat wisatawan domestik dan luar daerah sebanyak 12.198 orang pada tahun 2014 dan meningkat menjadi sebanyak 30.996 orang pada tahun 2016 (BPS, 2017). Peningkatan wisatawan snorkeling dikhawatirkan dapat merusak ekosistem terumbu karang di pulau Gili Labak. Hal ini dikhawatirkan karena kegiatan wisata bahari di area terumbu karang mempunyai dampak secara langsung terhadap keberadaan, populasi dan komunitas biota terumbu karang (Heil et al., 2006). Berjalannya kegiatan wisata bahari di kawasan terumbu karang dapat memperbesar resiko tekanan dan kerusakan ekosistem terumbu karang (Roche et al., 2016), serta dapat menurunkan peran ekosistem terumbu karang akibat tekanan antropogenik yang berasal dari kegiatan wisata (Pandolfi et al., 1995). Beberapa perilaku wisatawan snorkeling yang dapat merusak dan mengancam ekosistem terumbu karang diantaranya fins kick, sit-standkneel, siltting hand touch, pick up marine life dan harass marine life, collect objects or animals, serta body brush (Webler \& Jakubowski, 2016).

Penelitian ini bertujuan untuk mengetahui dampak kegiatan wisatawan sebelum, selama dan sesudah snorkeling terhadap ekosistem terumbu karang yang dikaji dengan mengetahui jenis karang yang mendominasi, status persentase tutupan terumbu karang di lokasi wisata bahari 
snorkeling dan persentase dampak wisata bahari snorkeling terhadap persentase tutupan terumbu karang di pulau Gili Labak Sumenep.

\section{MATERI DAN METODE}

Penelitian dilakukan pada bulan JuliAgustus 2019 di perairan Pulau Gili Labak dengan lokasi pengambilan data berada pada titik kordinat koordinat $07^{0} 12^{\prime} 17.2^{\prime \prime}$ LS dan $114^{0} 02$ '72.6” BT (Gambar 1). Pengambilan data persen penutupan karang dilakukan selama 2 minggu sekali. Pemantauan persen penutupan karang dibagi menjadi 2 lokasi pengamatan yaitu area kontrol (K) dan area Treatment (T) menggunakan 3 kali periode ulangan dalam rentang 2 minggu pada tiap pengamatan. Setiap kali pengamatan dilakukan sebanyak tiga periode yaitu sebelum (Before), selama (During) dan setelah kunjungan (After) wisatawan. Area kontrol merupakan satu lokasi terumbu karang yang jarang dikunjungi karena sulit dijangkau wisatawan, sedangkan area treatment adalah lokasi yang sering dikunjungi wisatawan untuk melakukan kegiatan snorkeling. Pengamatan penutupan karang dilakukan menggunakan transek survei menurut metodologi LIT (Line Intercept Transect) menurut English et al. (1997) dengan posisi transek di tempatkan secara paralel dengan garis pantai. Total panjang transek yang digunakan adalah 100 meter yang dibagi menjadi 5 ulangan dengan masing-masing ulangan memiliki panjang 20 meter merujuk pada metode English et al. (1997). Pengamatan persen penutupan karang dilakukan di lokasi titik transek yang dibuat permanen, dengan bantuan pasak dan tali nylon untuk menghindari bias data saat pengambilan data penutupan karang di lokasi penelitian periode berikutnya.

\section{Analisa Data}

Pengamatan dilakukan pada 4 komponen yaitu karang hidup, karang mati, fauna lain yaitu alga dan unsur abiotik diantaranya sand, rubble dan rock. Data kerusakan terumbu karang yang diperoleh dikelompokkan ke dalam tiga kategori (Tabel 1).

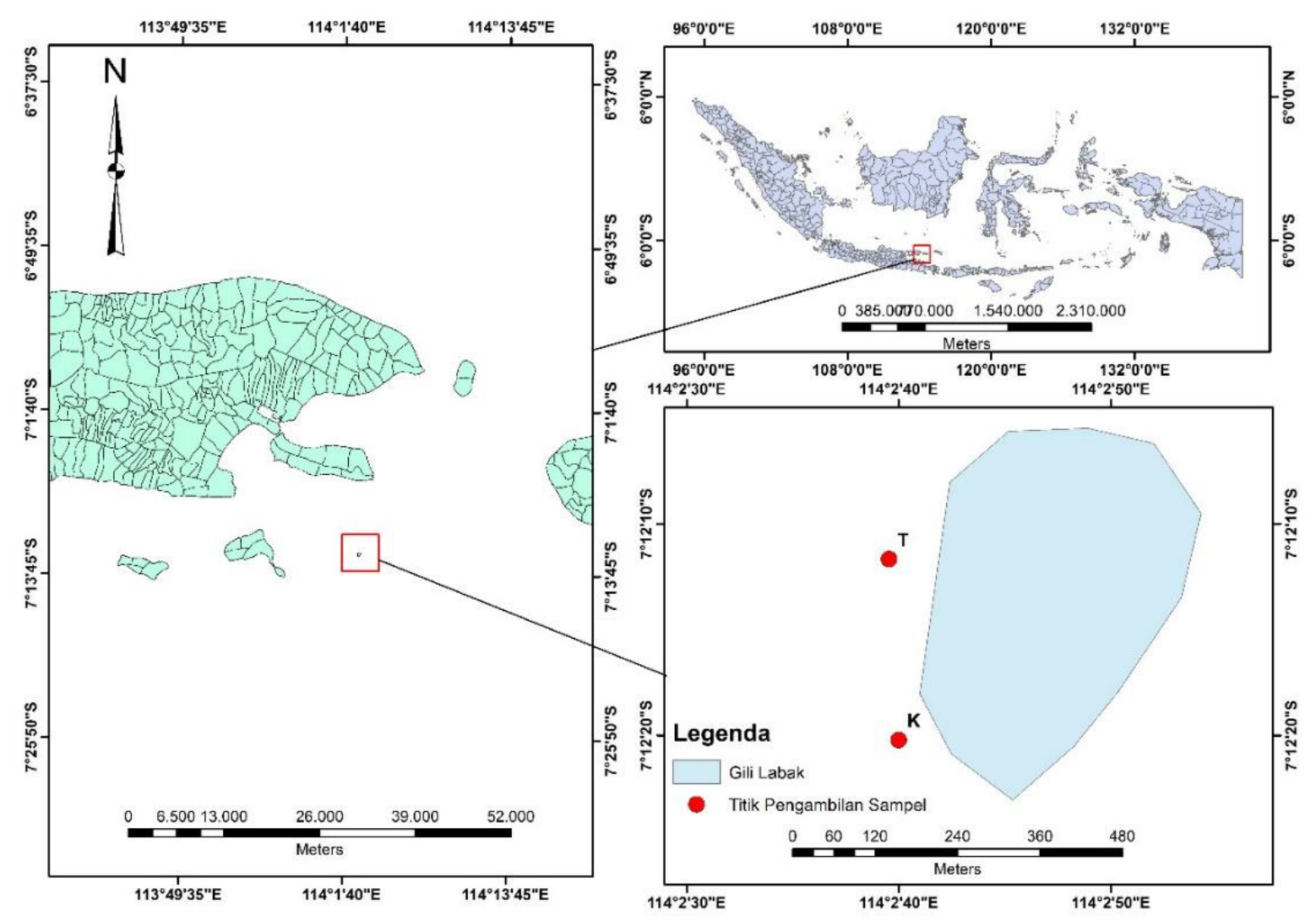

Gambar 1. Lokasi pengamatan pulau Gili Labak Sumenep Madura. K merupakan area kontrol dan $\mathrm{T}$ merupakan area treatment 
Tabel 1. Pengelompokan kategori kerusakan terumbu karang berdasarkan presentase kerusakannya akibat kegiatan wisata snorkeling (Muhidin et al. 2017).

\begin{tabular}{cll}
\hline No & Persentase & Kategori \\
\hline 1 & $0-30 \%$ & rusak ringan \\
2 & $30-70 \%$ & rusak sedang \\
3 & $70-100 \%$ & rusak besar \\
\hline
\end{tabular}

Analisis data untuk mengetahui dampak wisata snorkeling terhadap terumbu karang menyangkut prediksi tingkat kerusakan terumbu karang dimana nilai yang dihasilkan adalah persentase potensi kerusakan terumbu karang per tahun. Rumus yang digunakan adalah sebagai berikut (Yulianda, 2007).

$$
\mathrm{DWB}=\frac{\sum \mathrm{WiFi}}{\mathrm{Wp}} \cdot \frac{\mathrm{Lt}}{\mathrm{K}} \cdot \mathrm{P} \cdot \frac{1}{\mathrm{Lp}} \cdot 100 \%
$$

Keterangan: DWB $=$ Persentase dampak wisata bahari (\%); K = Potensi kerusakan ekologis akibat perilaku desktruktif pengunjung persatuan area untuk kategori wisata bahari tertentu ( $\mathrm{m}^{2} /$ orang), nilai $\mathrm{K}$ diperoleh dengan cara mengestimasi perilaku destruktif pengunjung yang memberikan tekanan terhadap ekosistem terumbu karang misalnya kegiatan 1 orang pengunjung snorkeling pada areal $1 \mathrm{~m}^{2}$ wisata terumbu karang di pulau Gili Labak; Lp = Luas area yang dapat dimanfaatkan untuk kategori wisata tertentu $\left(\mathrm{m}^{2}\right)$; $\mathrm{Lt}=\mathrm{Luas}$ area yang dibutuhkan untuk kategori

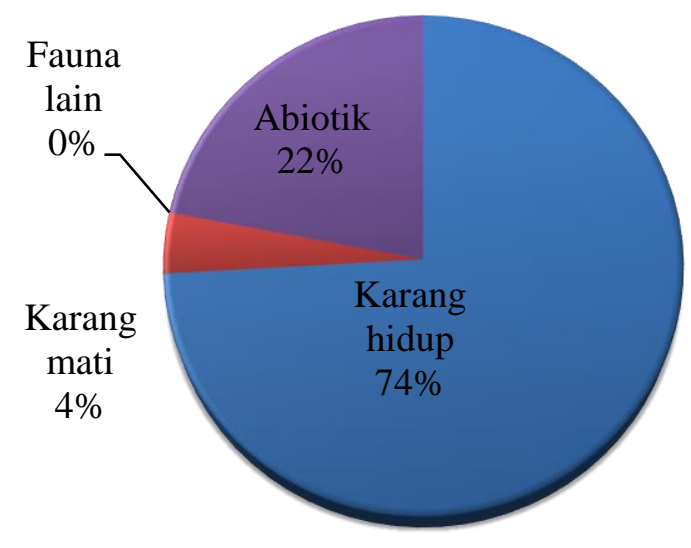

(a) wisata bahari tertentu $\left(\mathrm{m}^{2}\right) ; \mathrm{P}=$ Jumlah wisatawan untuk kategori wisata bahari tertentu (orang/tahun); $\Sigma W i F i=$ Jumlah waktu dan frekuensi perilaku pengunjung yang berpotensi merusak terumbu karang untuk kategori wisata tertentu (menit); Wp = Waktu yang dihabiskan oleh pengunjung untuk kategori wisata tertentu (menit).

Tutupan karang dan biota karang dianalisis dengan menggunakan rumus (English et al., 1997):

$$
\mathrm{Ni}=\frac{l i}{L} \cdot 100 \%
$$

Keterangan: $\mathrm{i}=$ persentase penutupan biota karang $\mathrm{ke}-\mathrm{i} ; \mathrm{Ni}=$ panjang total kelompok biota karang ke-i; $\mathrm{L}=$ panjang total transek garis.

\section{HASIL DAN PEMBAHASAN}

\section{Penutupan Terumbu Karang}

Hasil pengamatan menujukkan bahwa persentase penutupan lifeform karang di area snorkeling dan area kontrol perairan pulau Gili Labak berbeda-beda (Gambar 2). Grafik persentase penutupan lifeform karang di area pemanfaatan wisata bahari (area snorkeling) didominasi oleh karang hidup sebanyak $74 \%$ dan unsur abiotik sebesar 22\% (Gambar 2a). Nilai persentase berbeda ditunjukkan pada area kontrol. Area kontrol memiliki persentase bervariasi yaitu karang hidup sebesar $67 \%$, unsur abiotik sebesar $26 \%$ dan fauna lain 3\% (Gambar 2b).

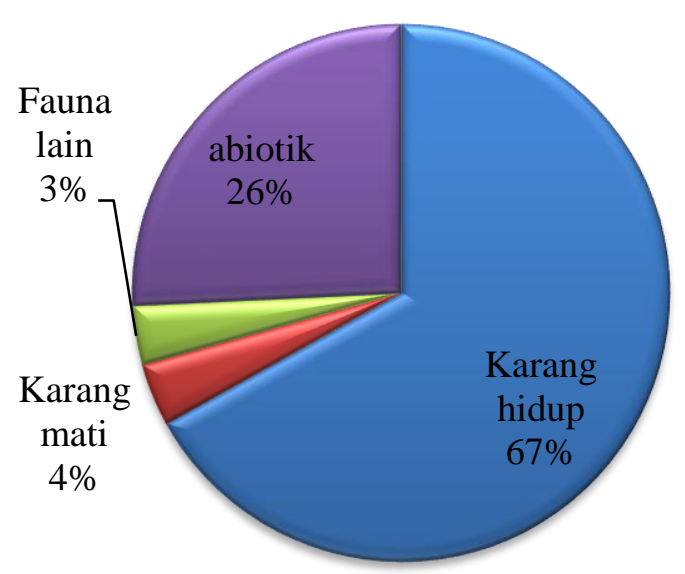

(b)

Gambar 2. Persentase penutupan lifeform ekosistem terumbu karang di area snorkeling (A) dan di area kontrol (B) 
Kedua lokasi memiliki persentase tutupan karang mati yang sama yaitu 4\%. Hal ini menujukkan bahwa perairan Gili Labak cocok untuk dijadikan sebagai pulau wisata snorkeling ekosistem terumbu karang di Kabupaten Sumenep. Perairan pulau Gili Labak berpotensi sebagai lokasi wisata snorkeling karena kawasan ini memiliki luas area terumbu karang sebesar $109.765 \mathrm{~m}^{2}$ dan nilai Indeks Kesesuaian Wisata snorkeling sebesar 78\% (Muhsoni, 2017).

Kondisi ekosistem terumbu karang pulau Gili Labak secara umum dapat diketahui dari persentase penutupan lifeform karang berdasarkan kategori oleh English et al. (1997) (Tabel 2). Hasil pengamatan menggunakan metode LIT menunjukkan bahwa persentase tutupan komposisi ekosistem terumbu karang yang hidup di perairan pulau Gili Labak cukup bervariasi (Tabel 2). Zona pemanfaatan wisata bahari khususnya area snorkeling memiliki 5 jenis karang Acropora yaitu Acropora Branching, Acropora Digitate, Acropora Encrusting, Acropora Submassive, Acropora Tubulate dan 6 jenis karang non Acropora yaitu Coral Branching, Coral Encrusting, Coral Foliose, Coral Massive, Coral Mushroom, dan Coral Submassive.

Jenis karang Acropora yang mendominasi pulau Gili Labak adalah Acropora Branching sebesar 19,88\%, sedangkan jenis non Acropora di dominasi oleh Coral Foliose sebesar 10,25\%. Acropora Branching merupakan salah satu jenis karang yang memiliki morfologi koloni bercabang

Tabel 2. Persentase penutupan lifeform karang pada 3 periode pengamatan

\begin{tabular}{|c|c|c|c|c|c|c|}
\hline \multirow{3}{*}{ Kategori } & \multicolumn{6}{|c|}{ Persentase Tutupan (\%) } \\
\hline & \multicolumn{3}{|c|}{ Area Snorkeling } & \multicolumn{3}{|c|}{ Kontrol } \\
\hline & $\begin{array}{c}\text { Minggu } \\
\text { ke-1 }\end{array}$ & $\begin{array}{c}\text { Minggu } \\
\text { ke-2 }\end{array}$ & $\begin{array}{l}\text { Minggu } \\
\text { ke-3 }\end{array}$ & $\begin{array}{c}\text { Minggu } \\
\text { ke-1 }\end{array}$ & $\begin{array}{l}\text { Minggu } \\
\text { ke-2 }\end{array}$ & $\begin{array}{c}\text { Minggu } \\
\text { ke-3 }\end{array}$ \\
\hline \multicolumn{7}{|l|}{$\begin{array}{l}\text { A. Karang hidup } \\
\text { Acropora }\end{array}$} \\
\hline 1. Acropora Branching (ACB) & 19,88 & 19,88 & 19,88 & 43,90 & 43,90 & 27,88 \\
\hline 2. Acropora Digitate (ACD) & 0,11 & 0,11 & 0,31 & - & - & 0,29 \\
\hline 3. Acropora Encrusting (ACE) & 0,12 & 0,12 & 0,12 & 1,49 & 1,49 & 0,58 \\
\hline 4. Acropora Submassive (ACS) & 18,91 & 18,85 & 19,08 & 6,32 & 6,32 & 14,84 \\
\hline 5. Acropora Tubulate (ACT) & 2,58 & 2,58 & 2,58 & 2,68 & 2,68 & 2,61 \\
\hline \multicolumn{7}{|l|}{ Non Acropora } \\
\hline 1. Coral Branching $(C B)$ & 8,19 & 8,19 & 8,19 & 1,81 & 1,81 & 6,06 \\
\hline 2. Coral Encrusting (CE) & 0,80 & 0,80 & 0,80 & - & - & 0,53 \\
\hline 3. Coral Foliose (CF) & 11,16 & 11,16 & 11,16 & 1,84 & 1,84 & 8,05 \\
\hline 4. Coral Massive (CM) & 10,25 & 10,25 & 10,25 & 9,08 & 9,08 & 9,86 \\
\hline 5. Coral Mushroom (CMR) & 0,47 & 0,47 & 0,47 & 0,16 & 0,16 & 0,37 \\
\hline 6. Coral Submassive (CS) & 1,53 & 1,48 & 1,53 & - & - & 1,53 \\
\hline \multicolumn{7}{|l|}{ B. Karang Mati } \\
\hline Dead Coral with Algae (DCA) & 3,92 & 3,92 & 3,92 & - & - & 3,92 \\
\hline \multicolumn{7}{|l|}{ C. Fauna Lain } \\
\hline 1. Soft Coral (SC) & - & - & - & 3,23 & 3,23 & 3,23 \\
\hline 2. Others $(O T)$ & - & - & - & 0,42 & 0,42 & 0,42 \\
\hline \multicolumn{7}{|l|}{ D. Abiotik } \\
\hline 1. Sand $(S)$ & 1,55 & 1,55 & 1,35 & - & - & 1,25 \\
\hline 2. Rubble (R) & 1,41 & 1,52 & 1,30 & 14,61 & 14,61 & 5,74 \\
\hline 3. $\operatorname{Rock}(R C K)$ & 19,12 & 19,12 & 19,06 & 14,46 & 14,46 & 17,50 \\
\hline
\end{tabular}

Keterangan: - = tidak ditemukan (Pengamatan selama 2 minggu sekali yaitu 2 minggu ke-1 hingga seterusnya). 
yang tumbuh pada perairan yang terlindung dari gelombang (Suryanti et al. 2011), perairan jernih dan lokasi terjadi pecahan ombak (Suharsono, 2010). Jenis karang ini merupakan jenis karang yang cepat tumbuh sehingga mampu mendominasi sebuah perairan, tetapi sangat rentan terhadap partikel tersuspensi yang tinggi dan kondisi arus yang cepat (Barus et al., 2018). Kemampuan mendominasi suatu perairan juga banyak ditemukan pada karang jenis Coral Foliose yang memiliki karakter morfologi tipis menyerupai lembaran-lembaran. Karang ini mampu berkoloni dengan membentuk lipatan dan tumbuh di lingkungan yang terlindung oleh arus (Barus et al., 2018). Jenis subtrat dasar perairan pulau Gili Labak untuk wisata snorkeling didominasi oleh karang dan pasir dengan tingkat kecerahan 100\% (cahaya mampu menembus dasar sedimen) (Muhsoni, 2017). Kondisi perairan demikian dapat menjadi subtrat yang cocok untuk pertumbuhan Coral Foliose dan Acropora Branching.

Pengukuran persentase tutupan lifeform karang yang menunjukkan fluktuasi di area snorkeling terdapat pada jenis karang Acropora yaitu Acropora Digitate dan Acropora Submassive, sedangkan jenis karang Non Acropora adalah jenis Coral Submassive. Acropora Submassive adalah jenis karang yang memiliki ciri morfologi percabangan berbentuk lempengan, sedangkan Acropora Digitate adalah jenis karang ciri morfologi percabangan rapat seperti jari-jari (Latuconsina, 2016). Fluktuasi persentase tutupan lifeform karang Acropora Digitate dan Coral Submassive dapat dikaitkan dengan keberadaan jenis karang tersebut. Menurut Suryanti et al. (2011), jenis karang Acropora Digitate di perairan Taman Nasional Karimunjawa banyak ditemukan pada kedalaman $3 \mathrm{~m}$ (kategori mudah dijangkau wisatawan), sedangkan Coral Submassive banyak dijumpai pada kedalaman $10 \mathrm{~m}$.

Indikator kerusakan terumbu karang di area snorkeling dapat dilihat pada persentase tutupan rubble (pecahan karang) yang menunjukkan persentase tertinggi pada pengamatan bulan ke 2 sebesar $1,52 \%$. Salah satu penyebab dari tingginya persentase tutupan pecahan karang di minggu ke 2 adalah banyaknya kesalahan perilaku wisatawan secara tidak sengaja maupun sengaja saat melakukan kegiatan snorkeling pada bulan tersebut di sekitar area pengamatan. Ada 6 perilaku wisatawan yang mengancam pertumbuhan karang di lokasi wisata snorkeling diantaranya fins kick (fins yang terkena karang saat melakukan snorkeliing), sit, stand, kneel (duduk, berdiri, berlutut pada karang), siltting (perilaku yang berpotensi membuat sedimen teraduk yang berpotensi menutup polip karang), hand touch (kegiatan menyentuh karang saat posisi wisatawan tidak stabil), pick up marine life dan harass marine life (perilaku menyentuh karang dan mengganggu biota yang ada di sekitar karang), collect objects or animals (perilaku mengambil dan mengoleksi benda-benda atau hewan yang ada disekitar karang), body brush (bagian tubuh yang tidak sengaja menyentuh karang) (Webler \&Jakubowski, 2016).

\section{Penutupan Karang Sebelum, Selama dan Sesudah Kegiatan Snorkeling}

Pengelompokan data persentase penutupan karang dibagi menjadi 3 kelompok yaitu karang hidup (HC) yang terdiri data Acropora dan non Acropora, karang mati (DCA), dan unsur abiotik (Rubble (R), Rock (RCK), Sand (S)). Hasil pengamatan menunjukkan bahwa terjadi penurunan persentase penutupan karang sebelum (before), ketika (during), dan setelah kegiatan (after) snorkeling pada area snorkeling (Gambar 3, 4 dan 5), namun tidak terjadi penurunan yang berarti pada area kontrol. Data pada minggu ke-1 menunjukkan bahwa persentase penutupan karang hidup (HC) sebesar 74,5\% sebelum (before) dan ketika snorkeling (during), namun berkurang menjadi $74,11 \%$ setelah kegiatan (after) snorkeling (Gambar 3). Penurunan persentase penutupan karang yang sama juga terjadi pada pengambilan data minggu ke-2 dan minggu ke-3. Persentase penutupan karang hidup (HC) pada pengambilan data kedua sebesar $74,11 \%$ sebelum (before) dan selama kegiatan snorkeling (during), tetapi berkurang menjadi 73,94\% setelah kegiatan (after) snorkeling (Gambar 4). Persentase penutupan karang hidup (HC) pada pengambilan data ketiga sebesar 73,94\% sebelum kegiatan snorkeling dan berkurang menjadi 73,86\% selama dan setelah kegiatan snorkeling (Gambar 5). Sementara itu tidak ada perubahan yang berarti di area kontrol di tempat tanpa kegiatan snorkeling (Gambar 6).

Hasil pengamatan pada masing-masing periode pengambilan data karang menunjukkan bahwa terjadi penurunan persentase kerusakan relatif kecil khususnya setelah kegiatan snorkeling (after) pada pengambilan data. Hal ini 
menunjukkan adanya dampak snorkeling terhadap penutupan karang. Selama waktu 6 minggu pengamatan terjadi penurunan total karang sebesar $0,64 \%$ (kategori rusak ringan), dimana sebagian besar kerusakan terjadi pada karang dengan bentuk pertumbahan branching misalnya Acropora Submassive maupun Coral Submassive.
Kajian pada titik snorkeling diketahui bahwa kontak fisik wisatawan terhadap terumbu karang seperti kegiatan duduk-berdiri-berlutut dan kontak fisik oleh operator wisata contohnya penambatan jangkar perahu pada area terumbu karang dapat menyebabkan kerusakan koloni karang berupa patahnya cabang karang, pengikisan permukaan

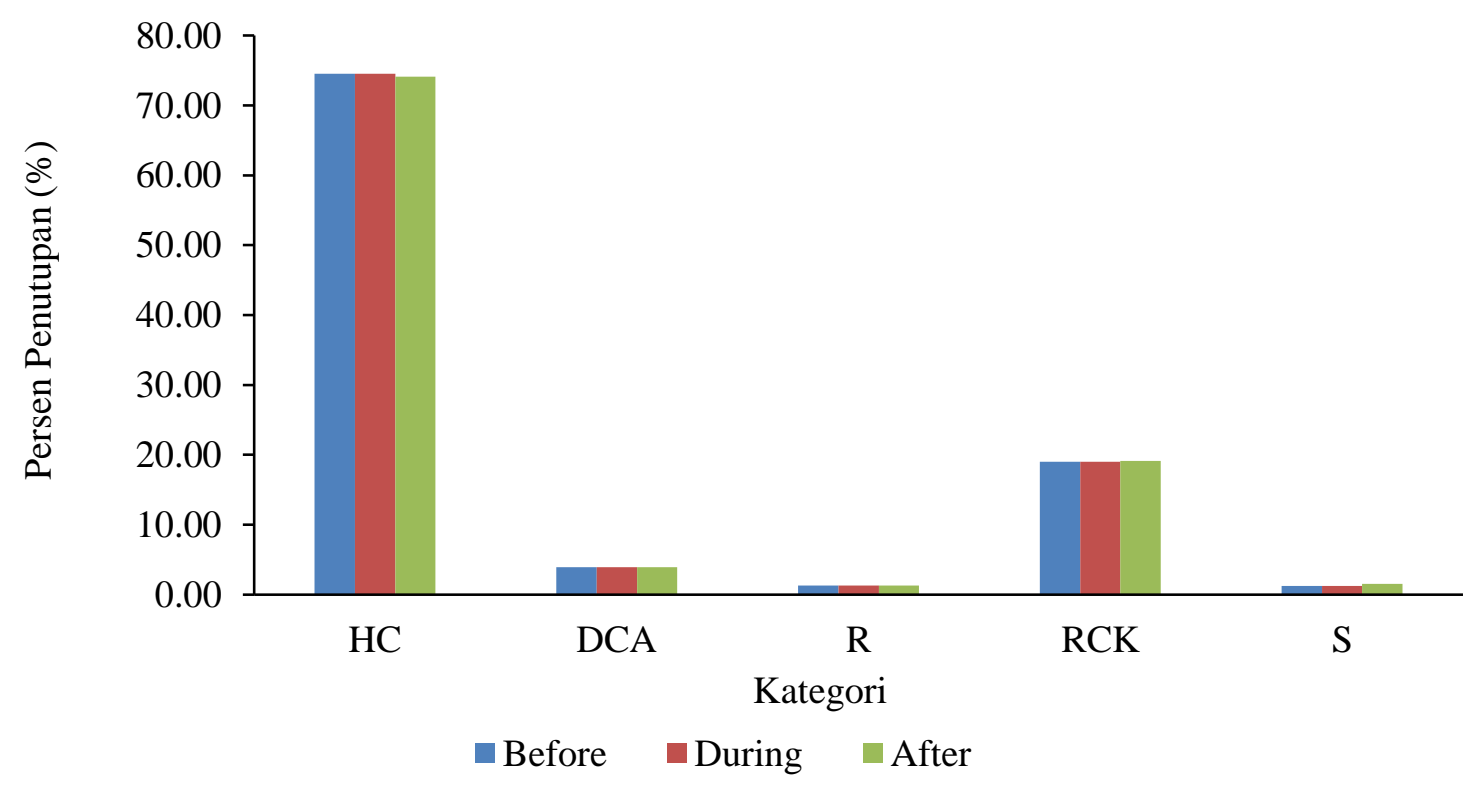

Gambar 3. Persen penutupan karang di Pulau Gili Labak sebelum (before), pada waktu (during), dan setelah kegiatan snorkeling (after) di area snorkeling pada pengambilan data minggu ke-1

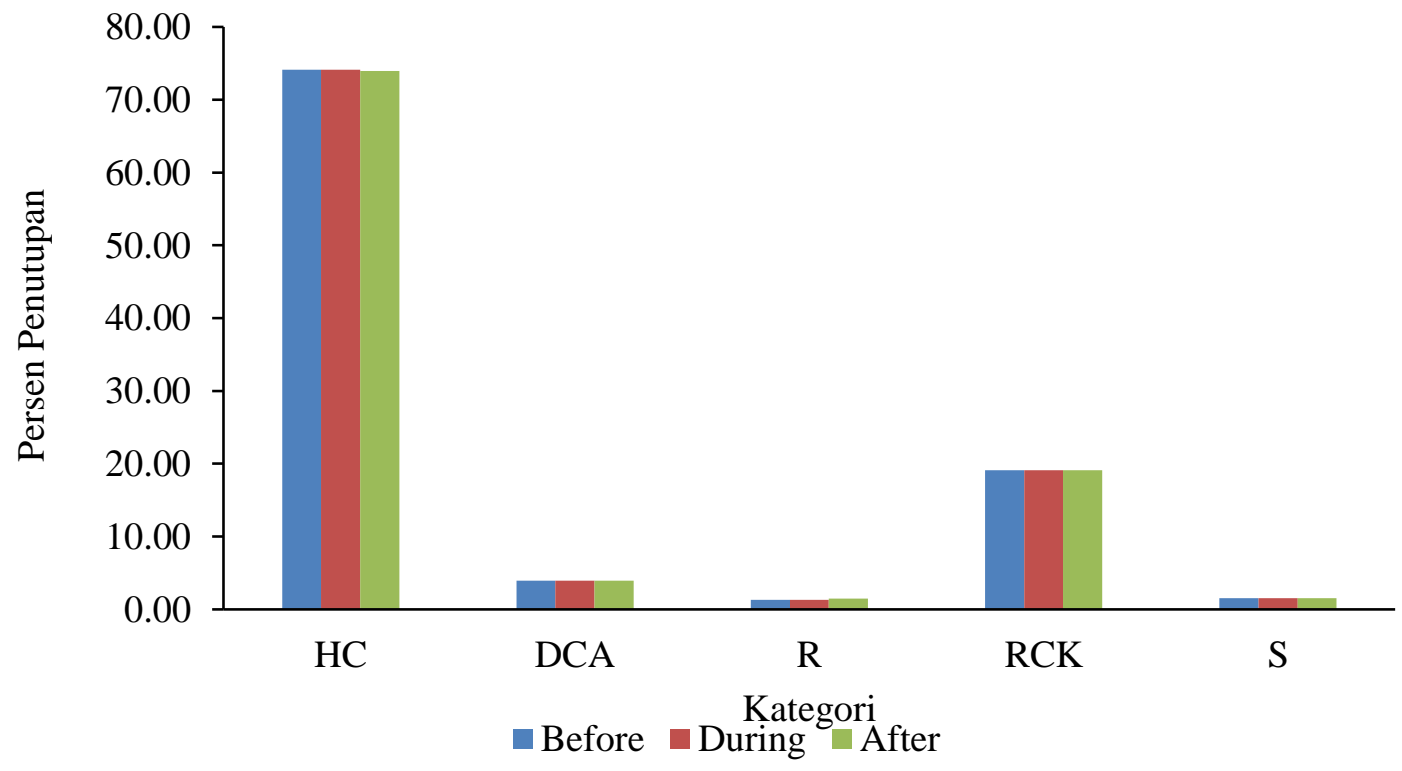

Gambar 4. Persen penutupan karang di Pulau Gili Labak sebelum (before), pada waktu (during), dan setelah kegiatan snorkeling (after) di area snorkeling pada pengambilan data minggu ke-2 


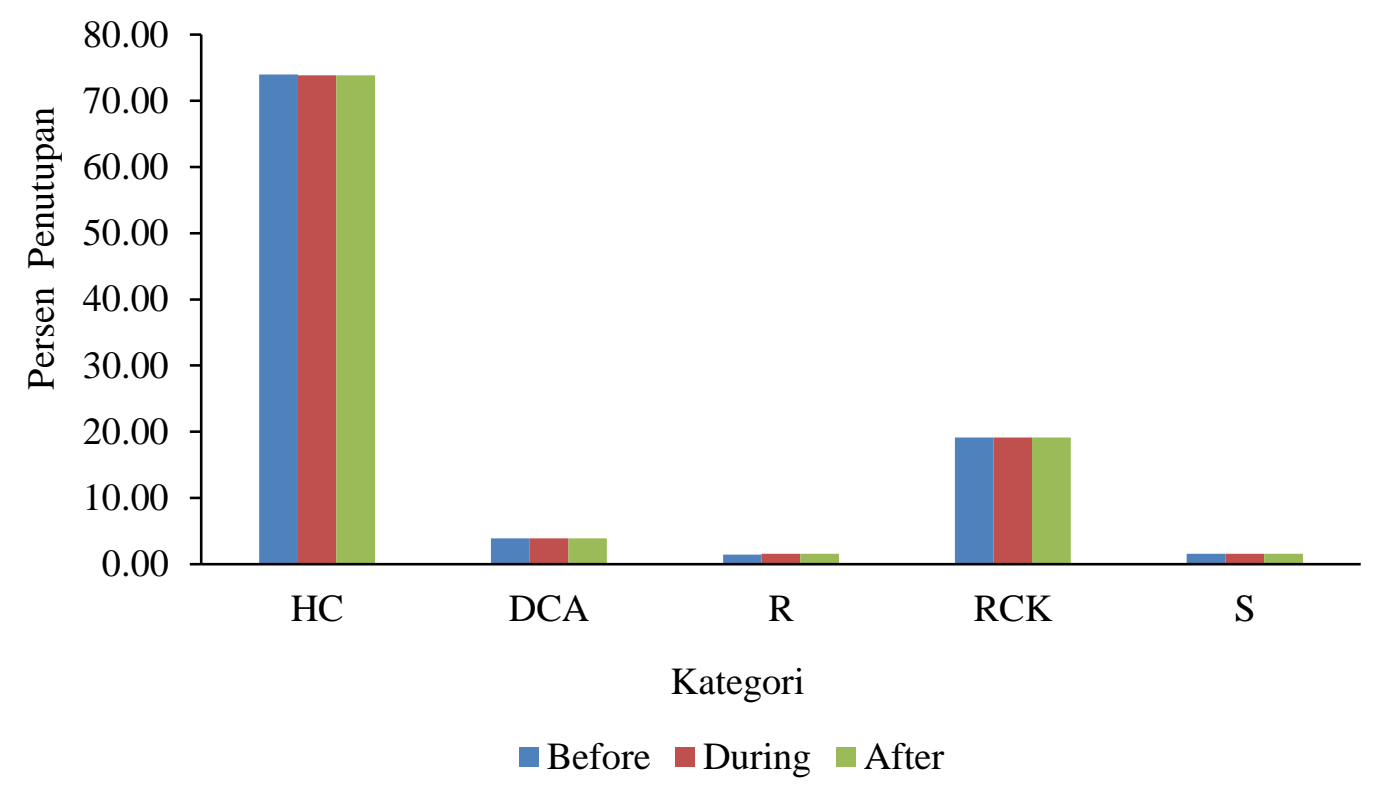

Gambar 5. Persen penutupan karang di Pulau Gili Labak sebelum (before), pada waktu (during), dan setelah kegiatan snorkeling (after) di area snorkeling pada pengambilan data minggu ke-3.

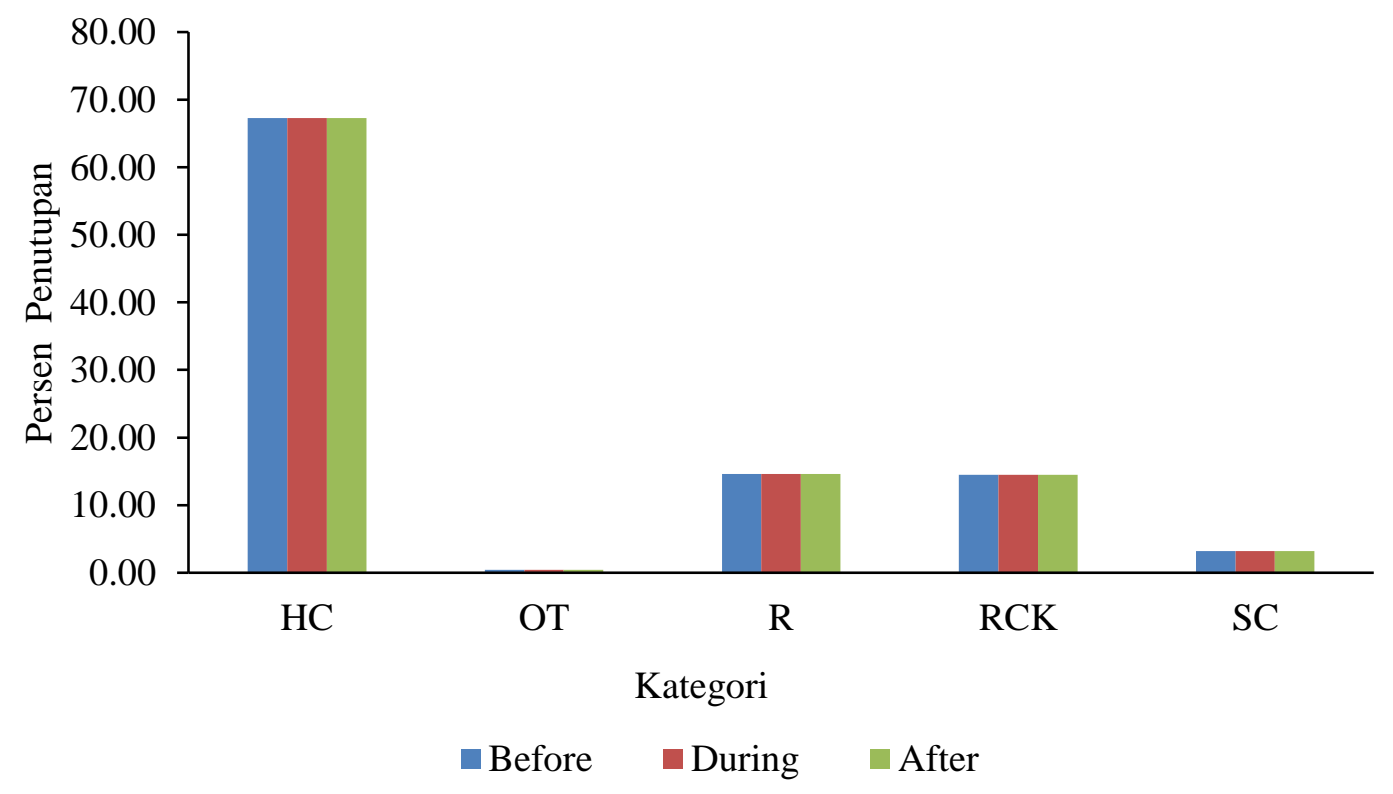

Gambar 6. Persen penutupan karang di Pulau Gili Labak di lokasi kontrol pada pengambilan data ketiga.

koloni karang, kematian koloni karang secara parsial (Akhmad et al. 2018). Kerusakan karang Acropora yaitu jenis karang branching bersifat kumulatif dimana tingkat kerusakan tergantung dari kekuatan skeleton karang dan banyaknya Rubble (R) yaitu jumlah cabang karang yang patah (Liddle \& Kay, 1987).

Dampak snorkeling terhadap penutupan karang juga dapat diketahui dari semakin meningkatnya jumlah pecahan karang (R) yang ada di area snorkeling pada 3 periode pengambilan data (Gambar 3,4,5,dan 6). Data pengamatan minggu ke-1 menunjukkan persentase penutupan pecahan karang (R) sebesar 1,30\% sebelum (before), selama kegiatan (during) dan setelah kegiatan (after) snorkeling. Persentase penutupan pecahan karang meningkat saat setelah kegiatan (after) snorkeling pada bulan ke dua 
sebesar 1,47\%, minggu ke- 3 sebesar sebesar $1,55 \%$. Melimpahnya patahan karang (R) di lokasi wisata snorkeling merupakan dampak yang diakibatkan dari ramainya kegiatan wisata snorkeling di area perairan dan dapat dijadikan sebagai indikator penurunan persentase tutupan karang di lokasi tersebut (Biondi et al., 2014). Ada 2 perilaku destruktif yang paling banyak dilakukan oleh wisatawan snorkeling yang menyebabkan banyaknya patahan karang branching yaitu tingginya intentitas menginjak dan menendang karang (Muhidin et al., 2017).

Hasil pengamatan juga menunjukkan bahwa hampir tidak ada kerusakan pada karang massive, meskipun berdasarkan pengamatan di lapangan banyak pengunjung yang berdiri di atas karang massive ketika berenang. Kegiatan snorkeling di area wisata bahari ekosistem terumbu karang merupakan salah satu kategori ancaman pada terumbu karang apabila tidak mengetahui cara melakukan posisi tubuh yang benar saat melakukan snorkeling (Allison, 1996). Kerusakan yang diakibatkan oleh goresan dan luka pada permukaan terumbu karang massive umumnya terjadi karena perilaku destruktif wisatawan yang memanfaatkan karang tersebut sebagai pijakan untuk berdiri ketika merasa panik dan kelelahan saat melakukan aktifitas snorkeling (Muhidin et al., 2017).

\section{Potensi Dampak Wisata Bahari (DWB) Snorkeling pada Terumbu Karang}

Analisa potensi dampak wisata bahari snorkeling pada terumbu karang di perairan Gili Labak pada tiap pengamatan (Tabel 3) merupakan salah satu upaya untuk mengetahui potensi daya dukung ekosistem terumbu karang di Pulau Gili Labak sebagai lokasi pengembangan wisata snorkeling. Analisa ini digunakan untuk mengetahui berapa persen gangguan dan kerusakan yang diterima ekosistem terumbu karang yang diakibatkan oleh wisata snorkeling.
Data hasil pengamatan menunjukan bahwa terjadi penurunan persentase kerusakan karang di area wisata snorkeling yang relatif kecil. Penghitungan persentase dampak wisata bahari snorkeling pada terumbu karang di perairan Gili Labak dengan estimasi $\mathrm{K}$ yaitu potensi kerusakan ekologis akibat perilaku desktruktif pengunjung persatuan area wisata sebanyak 1 orang dalam $\mathrm{m}^{2}$ terdapat pada tabel 3. Berdasarkan tabel 3 untuk kategori wisata bahari tertentu menunjukkan bahwa potensi kerusakan terumbu karang dari aktifitas wisata snorkeling selama 6 minggu pengamatan masuk dalam kategori rendah yaitu berkisar $0,052 \%$ hingga $0,085 \%$. Persentase dampak wisata bahari snorkeling tertinggi terjadi pada pengamatan pada minggu ke 2 sebesar $0,085 \%$. Hal ini diduga karena tingginya jumlah wisatawan yang mengunjungi pulau Gili Labak untuk melakukan kegiatan snorkeling dibandingkan jumlah wisatawan minggu ke 1 dan minggu ke 3.

Salah satu faktor penyebab kecilnya nilai persentase dampak wisata bahari snorkeling ini karena waktu pengamatan yang masih cenderung pendek yaitu berkisar 6 minggu, namun data persentase dampak wisata bahari tersebut menunjukkan bahwa ada indikasi dan potensi kerusakan terumbu karang yang diakibatkan oleh kegiatan wisata snorkeling di pulau Gili Labak. Potensi dampak wisata bahari snorkeling semakin besar akibat dari akumulasi kerusakan yang dilakukan oleh wisatawan. Hasil pengamatan yang sama diperoleh Muhidin et al. (2017) menyatakan bahwa kegiatan wisata snorkeling belum memberikan pengaruh signifikan terhadap persentase tutupan karang keras, namun berpengaruh langsung terhadap tingkat kualitas karang misalnya kerusakan pada ujung-ujung bagian atas koloni karang. Penyebab lain yang diduga menjadi penyebab kecilnya nilai persentase dampak wisata bahari snorkeling di lokasi pengamatan karena jenis karang yang

Tabel 3. Dampak Wisata Bahari Snorkeling pada Terumbu Karang di Pulau Gili Labak

\begin{tabular}{lccccccc}
\hline Waktu Pengamatan & $\begin{array}{c}\mathrm{P} \\
\text { (orang)* }\end{array}$ & $\begin{array}{c}\mathrm{K} \\
\text { (orang) }\end{array}$ & $\begin{array}{c}\mathrm{Lp}^{* *} \\
\left(\mathrm{~m}^{2}\right)\end{array}$ & $\begin{array}{c}\mathrm{Lt}^{* *} \\
\left(\mathrm{~m}^{2}\right)\end{array}$ & $\begin{array}{c}\text { Wp } \\
(\text { Menit })\end{array}$ & ¿Wifi & $\begin{array}{c}\text { DWB } \\
(\%)\end{array}$ \\
\hline 2 Minggu ke 1 & 34 & 1 & 109.765 & 500 & 180 & 60 & 0,052 \\
2 Minggu ke 2 & 56 & 1 & 109.765 & 500 & 180 & 60 & 0,085 \\
2 Minggu ke 3 & 40 & 1 & 109.765 & 500 & 180 & 60 & 0,061 \\
\hline
\end{tabular}

Keterangan : $*$ Jumlah pengunjung yang melakukan kegiatan snorkeling saat pengamatan; $* *=$ data luasan menurut Muhsoni (2017) 
mendominasi lokasi wisata adalah jenis Acropora. Menurut Raymond et al. (2006) karang berbentuk percabangan yang halus dan foliose seperti Acropora memiliki tingkat pertumbuhan yang lebih cepat namun tidak tahan terhadap tekanan akibat kegiatan wisata (mudah patah) dibandingkan karang dengan bentuk submasif dan masif, sehingga jenis karang Acropora lebih cepat melakukan proses regenerasi dibandingkan jenis submasif dan masif. Kemampuan jenis karang Acropora dalam melakukan regenerasi lebih cepat dibandingkan jenis karang lain juga disebabkan oleh keunikan jenis karang ini dalam memijah saat bereproduksi (Rani \& Jamaluddin, 2005). Genus karang Acropora dapat melakukan proses pembuahan sendiri yaitu telur dari karang ini terbuahi oleh sperma yang berasal dari koloni yang sama dan pembuahan silang yaitu telur yang dapat terbuahi dari koloni yang berbeda (Rani \& Jamaluddin, 2005). Penelitian lebih lanjut terkait pengamatan beberapa minggu setelah periode after kegiatan snorkeling disarankan untuk dilaksanakan untuk melihat ada atau tidaknya tanda-tanda regenerasi atau pemulihan karang khususnya karang dari jenis Acropora yang telah terjadi kerusakan akibat kegiatan wisata snorkeling di perairan Gili Labak.

\section{KESIMPULAN}

Berdasarkan hasil pengamatan dan analisis data persentase tutupan karang yang dilakukan di area snorkelling dan area kontrol pada tiga periode yaitu sebelum (Before), selama (During) dan setelah kunjungan (After) wisatawan dapat ditarik kesimpulan bahwa jenis karang yang mendominasi perairan Gili Labak adalah Acropora Branching dan Coral Foliose. Status penurunan persentase kerusakan karang di area snorkeling pulau Gili Labak relatif kecil dan ditemukan setelah kegiatan snorkeling (After) masuk dalam kategori rusak ringan. Persentase penutupan pecahan karang meningkat saat setelah kegiatan (after) snorkeling pada bulan ke dua sebesar 1,47\% dan minggu ke- 3 sebesar sebesar $1,55 \%$. Penurunan persentase karang ini menunjukkan adanya dampak kegiatan wisata snorkeling terhadap penutupan karang di pulau Gili labak. Analisa potensi Dampak Wisata Bahari (DWB) snorkeling pada terumbu karang di di perairan Gili Labak menunjukkan potensi kerusakan terumbu karang dengan kategori rendah.

\section{DAFTAR PUSTAKA}

Adibrata, S. 2013. Evaluasi kondisi terumbu karang di Pulau ketawai Kabupaten Bangka Tengah. Jurnal kelautan. 6(1):18-28.

Akhmad, D.S., Supriharyono \& Purnomo, W.P. 2018. Potensi kerusakan terumbu karang pada kegiatan wisata snorkeling di destinasi Wisata Taman Nasional Karimunjawa. Jurnal Ilmu dan Teknologi Kelautan Tropis. 10(2):419-429. doi: 10.29244/jitkt.v10i2.21 495.

Allison, W.R. 1996. Snorkeler damage to reef corals in the Maldive Islands. Coral Reefs. 15(4):215-218 pp. doi:10.1007/BF01787454

Barus, S.B., Prartono, T. \& Soedarma, D. 2018. Pengaruh lingkungan terhadap bentuk pertumbuhan terumbu karang di perairan Teluk Lampung. Jurnal Ilmu dan Teknologi Kelautan Tropis. 10(3):699-709. doi: 10.29 244/jitkt.v10i3.21516

Biondi, I., Munasik \& Koesoemadji. 2014. Kondisi terumbu karang pada lokasi wisata snorkeling di Kepulauan Karimunjawa, Jawa Tengah. Journal of marine research. 3(3):182-201. doi: 10.14710/jmr.v3i3.5990.

BPS. 2009. Kabupaten Sumenep Dalam Angka 2009. Keadaan Geografi. Badan Pusat Statistik Kabupaten Sumenep.

BPS 2017. Kabupaten Sumenep Dalam Angka 2017. Keadaan Geografi. Badan Pusat Statistik Kabupaten Sumenep.

BPS 2018. Kabupaten Sumenep Dalam Angka 2018. Keadaan Geografi. Badan Pusat Statistik Kabupaten Sumenep.

Damanhuri, H. 2003. Terumbu Karang Kita. Mangrove dan Pesisir. 3(2):33-38.

English, S., Wilkinson, C. \& Baker, V. 1997. Survey manual for tropical marine resources. Australian Institute of Marine Science. Townsfille, Australia. 390p. doi: 10.1017/ CBO9781107415324.004.

Hartoni, Ario, D. \& Yusli, W. 2012. Kondisi Terumbu Karang Di Perairan Pulau Tegal dan Sidodadi Kecamatan Padang Cermin Kabupaten Pesawaran Provinsi Lampung. Maspari Journal. 4(1):46-57. doi: 10.36706/ maspari.v4il.1: 342.

Hazrul, Ratna, D.P. \& Romy, K. 2016. Identifikasi Penyakit Karang (Scleractinia) Di Perairan Pulau Saponda Laut, Sulawesi Tenggara. Sapa Laut. 1(2):32-41.

Heil, L., Fernández-Juricic, E., Renison, D., Cingolani, A.M. \& Blumstein D.T. 2006. 
Avian responses to tourism in the biogeographically isolated high Córdoba Mountains, Argentina. In: Hawksworth, D.L., \& Bull, A.T. (eds) Vertebrate Conservation and Biodiversity. Springer, Dordrecht. 10091026pp. doi: 10.1007/978-1-4020-6320-6_12

Latuconsina, H. 2016. Ekologi Perairan Tropis: Prinsip Dasar Pengelolaan Sumberdaya Hayati Perairan. Yogyakarta: Gadjah Mada University Press. $183 \mathrm{hlm}$.

Liddle, M.J. \& Kay, A.M. 1987. Resistance, survival and recovery of trampled corals on the Great Barrier Reef. Biological Conservation. 42:1-18. doi: 10.1016/00063207(87)90049-8

Muhidin, Yulianda, F. \& Zamani, N.P. 2017. Impact of snorkeling and diving to coral reef ecosystem. Jurnal Ilmu dan Teknologi Kelautan Tropis. 9(1):315-326. doi: 10.292 44/jitkt.v9i1.17944.

Muhsoni, F.F. 2017. Potensi dan pengelolaan Pulau Gili Labak (Dan Kajian Pulau di Sumenep). Bangkalan: UTM PRESS. $161 \mathrm{Hlm}$

Pandolfi, J.M., Bradbury, R.H., Sala, E., Hughes, T.P., Bjorndal, K.A., Cooke, R.G., Sokal, R.R. \& Rohlf, F.J. 1995. The Principles and Practice of Statistics in Biological Research. $3 r d$ edn. W. H. Freeman and Co.: New York. $880 \mathrm{Hlm}$

Rani, C. \& Jamaluddin, J. 2005. Tingkah Laku Memijah Karang A. nobilis dan Pocillopora verrucosa di Terumbu Karang Tropik Pulau Baranglumpo, Makassar. Torani. 15(4):221228.

Raymond, Dizon, T. \& Yap, H.T. 2006. Effect of coral transplantation in sites of varying disntances and environmental conditions. Marine Biology. 4(5):933-943. doi: 10.1007/ s00227-005-0142-y.
Roche, R.C., Harvey, C.V., Harvey, J.J., Kavanagh, A.P., Mcdonald, M., SteinRostaing, V.R. \& Turner, J.R. 2016. Recreational diving impacts on coral reefs and the adoption of environmentally responsible practices within the scuba diving industry. Environmental Management. 58(1): 107-116. doi: 10.1007/s00267-016-0696-0.

Rozirwan, Bengen, D.G., Zamani, N.P., Effendi, H. \& Chaidir. 2014. Skrining potensi senyawa bioaktif sebagai antibakteri pada karang lunak dari perairan Pulau Pongok Bangka Selatan dan Pulau Tegal Teluk Lampung. Jurnal Ilmu dan Teknologi Kelautan Tropis. 6(2):283-295. doi: 10.292 44/jitkt.v6i2.

Suharsono. 2010. Jenis-jenis Karang yang umum dijumpai di perairan Indonesia. P3O- LIPI. Jakarta. $116 \mathrm{hlm}$.

Suryanti, Supriharyono \& Roslinawati, Y. 2011. Pengaruh kedalaman terhadap morfologi karang di pulau Cemara Kecil, Taman Nasional Karimunjawa. Jurnal Saintek Perikanan. 7(1):63-69. doi: 10.14710/ijfst. 7.1.63-69.

Webler, T., \& Jakubowski, K. 2016. Mitigating damaging behaviors of snorkelers to coral reefs in puerto rico through a pre-trip mediabased intervention. Biological Conservation. 197:223-228. doi: 10.1016/j.biocon.2016.03. 012

Yulianda, F. 2007. Ekowisata bahari sebagai alternatif pemanfaatan sumberdaya pesisir berbasis konservasi. Seminar Sains Departemen Manajemen Sumberdaya Perairan. Fakultas Perikanan dan Ilmu Kelautan. Institut Pertanian Bogor: Bogor. 21 Februari 2007. 7 hlm. 